\title{
Er morsmelk giftig eller livreddende?
}

\author{
Kunnskapsgrunnlaget om effekter av kontaminanter i morsmelk er under utvikling, \\ men fremdeles mangelfullt. Inntil vi vet mer bør vi unngå å skape utrygghet i befolkningen \\ ved å så tvil om de aktuelle anbefalinger. Det er kilden til giftstoffene, ikke ammingen \\ vi vil til livs.
}

Norge ligger på ammetoppen i verden. I over tjue år har norsk ammepolitikk vært innrettet for å oppnå fullamming for flest mulig. Og langt på vei har vi lyktes. I dag ammer mer enn $80 \%$ av norske kvinner sine barn frem til fylte seks måneder, et resultat andre land bare kan drømme om. Fra 2007 er nå de offisielle anbefalingene at barn bør fullammes i seks måneder, og at ammingen bør fortsette til barna har fylt 12 måneder. Men i økende grad er nå spørsmålene blitt reist: Er det virkelig sunt å amme mer enn en kort tidsperiode etter fødsel? $(1,2)$ Det undertegnede klarer å lese ut av konklusjonene er en svak negativ assosiasjon mellom heksaklorbensen (HCB)-konsentrasjon i brystmelk og fødselsvekt hos røykere. Det er imidlertid mange faktorer i tobakksrøyk som påvirker fødselsvekt og fosterutvikling negativt, med solid dokumentasjon i den vitenskapelige litteratur.

\section{Manglende kunnskapsgrunnlag}

I de sirkumpolare områder har vi det som kalles det arktiske dilemmaet: nemlig at gode fødeemner og kontaminanter kommer fra de samme kilder og overføres til barnet vesentlig gjennom morsmelk og tradisjonelt kosthold. De studiene som er gjort i disse områdene, der miljøgiftkonsentrasjonene er betydelig høyere enn lenger sør i Europa, har imidlertid ikke gitt grunnlag for noen tilrådninger om å redusere ammefrekvens og ammeperiode (3). Kunnskapen er fremdeles svært mangelfull. AMAP, som er en arbeidsgruppe under Arktisk Råd, har samlet den tilgjengelige kunnskap om miljøgifter og svangerskap i gruppens siste rapport (3). I det tilhørende EU-prosjektet ArcRisk utarbeides det nå en metaanalyse av tilgjengelig vitenskapelig litteratur om kontaminanter og potensielle effekter på reproduktiv helse (4). Det er vesentlig studier av barnekohorter over mange år som kan gi svar på de sentrale problemstillinger om kontaminantenes skadeeffekter på fostre og små barn. Disse studiene er tidkrevende og dyre å utføre. Nå begynner vi å få en del svar som kan brukes direkte

i folkehelsearbeidet $(5-8)$.

Det foregår også en rekke studier knyttet til ArcRisk, der man knytter sammen flere kohorter for å skaffe store nok studiegrupper og sikre at studiene er kompatible. Alle sirkumpolare land er med på disse studiene. Man følger grupper av barn over mange år, med analyser av kontaminantkonsentrasjoner i brystmelk og blod, samt registrering av definerte utviklingsparametere hos barna. Et overvåkingsprogram kun i form av analyser av kontaminanter i brystmelk er langt fra nok til å avdekke effekter det bør gripes fatt i. I tilknytning til klimaendringene er heller ikke brystmelk det beste medium for å undersøke alle relevante kontaminanter (9). For metaller og sporelementer (for eksempel kvikksølv og selen) er blod et bedre egnet medium. En viktig del av den informasjonen vi trenger for å se på helseeffekter, blir borte

i brystmelkprøvene. Kvikksølvproblematikken vil komme for fullt i takt med klimaendringene (3).

\section{Føre-var-prinsippet}

Når kunnskapen er så mangelfull som den er i dette tilfelle, hva gjør vi da? Etter mitt skjønn må vi være ekstra varsomme når vi skal formidle helseopplysninger og helseråd til befolkningen. Hvis vi sår tvil om ammingens positive effekter, kan vi gjøre mye galt for folkehelsen og det gode kosthold for neste generasjon. Grønlandsk historie gir grunn til ettertanke (3). Et brått og ugjennomtenkt skifte i kostholdsråd og ammeråd for den grønlandske befolkning i 1980-90-årene medførte at kosten ble mangelfull og ubalansert. Konkrete følger var økt forekomst av hjerte- og karsykdommer og diabetes. Her brukte man ikke føre-var-prinsippet i folkeopplysningen. Dette er det nå grepet fatt $i$, men det er lettere å rive ned enn å bygge opp (3). Førevar-prinsippet bør derfor være grunnleggende $i$ alle studier der man vurderer miljøgifteffekter på fosterutvikling, svangerskapsutfall og barns utvikling i de første leveår.

Hva kan vi gjøre mens vi venter på mer kunnskap? Vi bør gi gode kostholdsråd for den delen av befolkningen som er i reproduktiv alder og fjerne de kostholds- elementene som har dokumenterte høye konsentrasjoner av kontaminanter. Vi bør sette søkelyset på kilder til giftstoffene og tiltak for å fjerne disse. Miljøverndepartementet har satt ned et utvalg (10) som skal levere en NOU våren 2010 med konkrete forslag til tiltak både nasjonalt og internasjonalt med mål om et giftfritt samfunn etter 2020. Det er langt frem dit, men det er direkte uklokt å reise spørsmål om skadevirkninger av historiens beste næringskilde før vi har gjort det vi kan for å fjerne kildene til giftstoffene.

\section{Jon Øyvind Odland \\ jon.oyvind.odland@uit.no \\ Det helsevitenskapelige fakultet \\ Universitetet i Troms $\varnothing$ \\ 9037 Tromsø}

Oppgitte interessekonflikter: Ingen

Litteratur

1. Eggesbø $\mathrm{M}$, Stigum $\mathrm{H}$, Longnecker MP et al. Levels of hexachlorobenzene (HCB) in breast milk in relation to birth weight in a Norwegian cohort. Environ Res 2009; 109: 559-66.

2. Bratlid D. Miljøgifter i morsmelk. Tidsskr Nor Legeforen 2009: 129: 2606-9.

3. AMAP Assessment 2009: Human Health in the Arctic. Arctic Monitoring and Assessment Programme (AMAP), Oslo: AMAP, 2009.

4. O.A.Sys - Ocean Atmosphere Systems. www.oasys-research.de/projects/ plonearticlemultipage.2009-04-29.6887383578/ plonearticle.2009-04-29.9101699270 (29.1.2010)

5. Bjørling-Poulsen M, Andersen HR, Grandjean P. Potential developmental neurotoxicity of pesticides used in Europe. Environ Health 2008; 22: 50.

6. Grandjean P, Budtz-Jørgensen E, Barr DB et al. Elimination half-lives of polychlorinated congeners in children. Environ Sci Technol 2008; 42: 6991-6.

7. Grandjean P, Heindel JJ. In utero and early-life conditions and adult health and disease. $\mathrm{N}$ Engl J Med 2008; 359: 1523.

8. Plusquellec P, Muckle G, Dewailly E et al. The relation of environmental contaminants exposure to behavioral indicators in Inuit preschoolers in Arctic Quebec. Neurotoxicology 2009; først på nett 23.10.2009.

9. Sandanger TM, Anda EE, Dudarev AA et al. Combining data sets of organochlorines (OCs) in human plasma for the Russian Arctic. Sci Total Environ 2009; 407: 5216-22.

10. Miljøgiftsutvalget. www.miljogift.no (1.2.2010).

Manuskriptet ble mottatt 10.1. 2010 og godkjent 21.1. 2010. Medisinsk redaktør Anne Kveim Lie. 